\title{
Modern Youth and Transethnic Identities
}

\author{
Aleksandra Ålund
}

The self-archived postprint version of this journal article is available at Linköping University Institutional Repository (DiVA):

http:// urn.kb.se/ resolve?urn=urn:nbn:se:liu:diva-45064

N.B.: When citing this work, cite the original publication.

This is an electronic version of an article published in:

Ålund, A., (1991), Modern Youth and Transethnic Identities, European J ournal of Intercultural Studies, 2(2), 49-62. https:// doi.org/ 10.1080/ 0952391910020204

Original publication available at:

https:/ / doi.org/ 10.1080/ 0952391910020204

Copyright: Taylor \&amp; Francis

http:/ / taylorandfrancis.com/journals/ 


\title{
Modern youth and transethnic identities
}

\author{
Aleksandra Alund \\ Reader, Institute of Sociolog;, University of Umeå, Sweden
}

\begin{abstract}
New cosmopolitan local communities, in Stockholms multi-ethnic suburb's as in other European cities, harbour the preconditions for the transgression of narrow social and cultural borders. Here, in a dynamic interplay and articulation of tradition and modernity, the antagonisms and struggles of the past are connected with the present dilemmas and ordeals of the immigrant experience, producing new amalgamated forms of cultural expression and political alternatives.
\end{abstract}

The modern world has been described as an aggregation of private interests groups, living in 'windowless monads' (Berman, 1983: 34); a windowless social darkness indicating a civilisation in crisis. Social fragmentation, legitimation crises and ambiguous identities have come to be associated with reactive discontent. self-isolation, ' a process of fraternity by exclusion of 'outsiders' (Sennett 1977: 266), authoritarian populism, nationalism and racism; that is by reactive communities which have fragmentation as their underlying logic, 'as the units of people who are considered to belong become smaller and smaller' (ibid.). It is a form of fraternity which leads to fratricide (ibid.). However, modernity has also come to be connected with 'cultural flows in space' (Hannerz, 1990: 1), with the loosening of social and cultural boundaries, with migration, with the expansion of 'world culture', with the cultural melting pots known as 'global cities', a cultural variety, movement, transformation and coming together which has inspired visions of a future with new possibilities (cf. Berman. 1983; Hannerz 1990). New boundary transcending cultures and life styles, including underground forms, are emerging in the inner cities of Britain, in Berlin's Kreuzberg neighbourhood, in Paris, as well as in Sweden's multiethnic suburbs. These areas pulsate with a completely different historical dynamic than the fragmented disorder praised by postmodernism (Rogild 1988: 187). These life rhythms penetrate society discreetly from below, as Stuart Hall argues. Hence, in a cultural sense, Britain is turning 'black'; even the young white Britain. The multicultural Britain which was predicted ten years ago already exists, says Hall (interviewed in Rogild. 1988: 183). But, he continues, this fact, the significance of and inspiration from Black society and culture, is something of which we in Europe are not usually aware. New cultural dispositions have difficulty breaking through the power of hegemonic cultural definitions to decide what appears to be in that what is.

The 'invisibility' which Hall discusses is hardly accidental. It seems to reflect the lack of societal legitimacy for an actually existing plurality. In Sweden, as Ludvig Rasmusson (1990: 6-7) expresses it. "the cultural establishment tends towards a uniformity and 


\section{Alekdandra Ålund}

intolerance... which through a combination of provincialism with obsession with the American hinder those immigrants who try to create something new'. The problematic which is connected to this has institutional, ideological and social scientific dimensions. The role of research, in Sweden as well as in Britain, is important in connection with this 'epistemological problem'. As an integrated part of society's ideological and institutional practices research produces labels, concepts and images of reality, through which symbolic and social hierarchies are maintained or recreated. This 'power of definition' is an essential but not always acknowledged aspect of the exercise of power.

In the following we discuss instances of inventive, border transcending cultural creativity among immigrants as embodying resistance towards segregating definitions. Transethnic social relations, new 'syncretic' cultural forms, bridge-building cultural systems of meaning, appear to express a common, collective confirmation through which an alternative, authentic, performance on the public stage emerges (cf. Gilroy 1987). This intercultural ordeal in time and space goes beyond style-bound expressions and timeadaptated signals. At a more profound level, in a hidden dialectical unity of continuity and discontinuity, numerous encounters with the past are going on. In the condensed interplay between tradition and modernity, a generally important emancipatory potential is submerged. The symbolic 'wrestling with ghosts' embedded in a syncretic identity work and transcultural bricolage represents one constructive answer to the crisis of modern consciousness.

\section{The culturalist construction of boundaries}

In Sweden it appears as if language plays a 'decisive role' (Stroud and Wingstedt, 1989: 8 ) in creating boundaries and separateness between ethnic groups, in research as well as in the public debate. Yet reality seems to oppose itself to the canonised understanding of cultural order and hierarchy. The notion 'Rinkeby Swedish' (rinkebysvenska) has in recent years come to our attention. Rinkebysvenska or rinkebyska refers to a mixed 'creole' language which has evolved among the ethnically mixed groups of young immigrants in Stockholm suburbs such as Tensta and Rinkeby. These newly created Stockholm dialects have been described as having 'linguistic traits which deviate strongly from Standard Swedish and as inherently irritating for individuals with strongly normative linguistic sentiments', Stroud and Wingstedt write (ibid.). Rinkeby Swedish has attained a stigmatising content similar to the situation of 'double semi-lingualism' described for immigrant youth who are presumed to lack linguistic competence in both their native language and Swedish. Research has conventionally.viewed Rinkeby Swedish with a cool disinterest. The negative ideological content of Rinkeby Swedish can be understood as part of a 'boundary repairing' strategy reconstituting vague or destroyed ethnic boundaries (Stroud and Wingstedt: 8). But pointing out 'that which is different' and, at the same time, 'emphasising that which is risk-filled in non-normative conduct' serves to segregate and marginalise groups that deviate (ibid.). The 'loaded' content thereby contributes to constructing a reality of separateness, organising and formulating attitudes to the others while simultaneously reflecting an ethnocentric view of 'one's own'; that is, Swedishness. Behaviour which can be linked to immigrants is labelled, problematised and symbolically loaded with anxiety. The fear arises that linguistic deviations, like an infection, can sneak their way into and pollute Standard Swedish with 
un-Swedish characteristics (ibid.: 8). Rinkeby Swedish is thus viewed as a cultural and social problem, as a threat to the prescribed order.

In a more positive understanding, however, Rinkeby Swedish may indicate a double cultural competence, as 'the second language', a 'group dialect', which serves to identify the members in the group as simply 'immigrant youth' (Kotsinas, 1985: 283). That is for the youth it is not something negative but, rather a 'secret language', a vehicle for the production of consciousness and resistance (cf. Jones, 1988). In this sense, Rinkeby Swedish consolidates a composite local identity and a belonging to a mixed community which 'ethnically' includes even Swedishness. I Hjärtat av Tensta (In the Heart of Tensta, 1989 ) is a collection of poems, narratives and images from the multi-ethnic Tensta high school. It tells of the need for love, for openness and for the need to belong. 'To live in Sweden demands... that once opens up, experiences a great friendship', Mary Marin de Vidal (1989: 117) writes. Of young people in Tensta, it could be said, as of the Rinkeby youth, that they 'are absolutely not so fixated about where people come from. A buddy is a buddy. One does not concentrate on and powwow about where one comes from' (Tengvall, 1986: 34). A school teacher says about her class where the "whole world has 'beamed' together', that 'the young people are worth admiring. They move like fish in the water out there. Sometimes I am green with envy when I think of them. They have friends from so many different countries. From these friends they leam things which I myself at that age could only read about in books' (ibid).

During my own research in Stockholm I came into close contact with a group of high school girls from one of the suburbs. These young people's 'company', as they call it, is both ethnically and sexually mixed, and includes Yugoslavs, Turks, Greeks, Hungarians, Italians, Swedes and others. Their common language is Swedish loaded with a whole lot of words from the arsenal of ethnic variety. It seems as if this group of youth represents the growth of a new way of life on the Swedish cultural scene, similar to the Rinkeby Swedish phenomenon. This concerns not only the emergence of a new language or dialect but of extensive transcultural identity work. The contrast to dominant Swedish stereotypes of rootlessness, maladaption and ethnic conflict in the 'concrete ghettos' of the suburb is obvious. These young men and women seem to share a cultural way of life which resembles that which British researchers have characterised as 'syncretic culture' (Gilroy, 1987; Jones, 1988) where 'culture does not develop along ethnically absolute lines but in complex, dynamic patterns of syncreticism' (Gilroy, 1987: 13).

Whether similar forms of social-cultural life are developing in Sweden has not been researched. Immigrant youth achieve a kind of 'negative fame' as 'culturally split', 'bad boys' and the like. The public debate, immigrant research as well as public commissions tend to focus on cultural differences, ethnic boundary maintenance, conflicts and problems. 'Culture' is squeezed into static and narrowly defined stereotypes, glossing over amalgamated cultural forms which, especially among youth, are already a fact as well as a genuine alternative.

\section{Negative fame}

The importance of a dynamic view of cultural and social variety has often been discussed in Sweden (Ålund, 1985; Bjurström 1985; Westerberg 1985; Schierup and Ålund, 1987; Arnstberg 1989; Daun and Ehn, 1988). In the public debate, nevertheless, it often appears as if it is only the immigrants who differ from a homogeneous 'Swedish' culture. Being 
contrasted to 'normality' especially immigrant youth and immigrant women in various ways become 'cases' and are subjected to what (in the spirit of Michel Foucault) could be designated 'negative fame'. Research has described immigrant youth identity in terms of stereotyping problem notions like 'between two cultures' and 'split identities', at the same time as this problem image is full of contradictions and lacks adequate empirical evidence.

'Immigrant cultures' are considered to be burdened by the weight of traditionalism, while the detraditionalised Swedish culture is represented as more uniform and homogeneous than it actually is. 'Modern' and 'traditional' are polarised and the individual's identity crises are related to difficulties in maintaining the integrity of 'cultures'. In an ethnocentric way the 'integration' process is described as a uniform adaptation of the deviant/foreign to the normal, the modern, the Swedish. Diverse measures of 'proximity' to or 'distance' to Swedishness (Similä, 1987; Lange, 1987; Westin, 1987) have been employed as indicators for how close or how far immigrants have come in a process of integration. Comparisons within and between ethnic groups (eg. Ouvinen-Birgerstam, 1984; Lithman, 1987) are used to indicate where each group is located on the scale of integration and how much their own culture has been 'diluted' (Bäck, 1989; Similä, 1987).

While Swedish immigrant research has focused on cultural differences, research on youth issues has tended to question assumptions about the uniformity of Swedish culture. Simple representations of 'Swedish' and 'Immigrant' culture are questioned (Westerberg, 1987). Here, instead, we meet a tendency to draw attention to conflicts connected with class-related contradictions. Hermansson (1988: 117), for example, identifies 'workers' culture 'as an important dimension in the explanation of the immigrant youth's life-world, which together with elements from diverse youth cultures, determines the cultural frame of reference. While this contributes to important insights, there is also a risk that a unilaterally class-based approach may underestimate the productive potential of culture in the immigrant context. There is a tendency to de-emphasise culture, inasmuch as its potentially 'difficult' or 'troublesome' content - as a barrier - is presumed to inhibit communication between Swedish and immigrant youth (Westerberg, 1987: 187). Culture is rather seen as a separate pathway into a common discourse on general life questions.

However, a too keen toning down of 'culture' is just as problematic as an ethnocentric polarisation of cultures or a cultural ranking. 'Split or diffused in a dozen directions' new generations of ethnic youth show a great daring and fantasy when it comes to 'transforming disintegration into a new form of order' (paraphrasing Berman, 1983: 322; see also, Schierup and Allund, 1987). But without involvement in their own roots there is considerable risk that there will develop 'a freedom from culture' (Ziehe and Stubenrauch, 1983) which simply means that the 'liberated' individual is expropriated by the structures of domination (Schierup and Ålund, 1987).

This kind of outcome is, for example, indicated in Bjurström's (1985) discussion on Swedish immigrant youth's options 'for choosing their culture'. Bjurström seems to operate with a kind of 'cultural cross-pressure' between one's own 'ethnic' and a 'Swedish' culture. But, while immigrant youth are gradually 'liberated from the pressure' of their parents' traditions, at the same time there emerges an increased amount of confusion, insecurity, rootlessness and 'vacuum'. Exposed to ongoing rupture of norms and de-traditionalisation, immigrant youth risk throwing out both 'traditional Swedish' 
culture and the 'immigrant cultures', orienting themselves to commercial leisure-time and cultural life-style packages, either passively or by creating new mixes of styles with ingredients from the media market (ibid: 38-39). Although Bjurström mentions the emergence of 'new contexts of meaning', identity options and life styles, the impression is of an apparent picking and choosing on the surface of the gamut of prefabricated life-styles for sale on the consumer and media markets. Ignored, however, is the fact that a creative coping with cultural antagonisms can have essential significance for the creation of new identities. Placed on the outside of their own cultural backgrounds young people are excluded from authentic alternatives and are indeed running the risk to be expropriated by the structures of domination. A detachment from the past may also lead to a detachment from the future. When the 'cultural multitude' consolidates itself into a contrast between 'Swedish' and 'immigrant', and when new life-styles are seen as finished costumes on the commercial supermarket, there is a risk of fabricating (in theory and real life) an 'identity chaos' or 'in-between 'cultural conflict and an 'either/or' choice between cultures. Boundary transcending and amalgamating cultural bricolage remains unnoticed or suppressed. Comparing the situation in Britain and Sweden, Bjurström (1985: 37) argues that Swedish young people are not confronted with linguistically, nationally and ethnically mixed environments while growing up. Yet, in contrast to what Bjurström all too rapidly asserts, in reality, Sweden too is becoming 'black' (or 'blackheaded', if one correctly glosses the Swedish word svartskalle). This is not least articulated in music. One example is what is in Britain called 'Nordic beat', the new Swedish rock carried forth by a young generation of black and 'ethnic' Swedes (as, for example. Titiyo, Papa Dee, Leyla $\mathrm{K}$ and DaYeene, just to mention a few of the most well-known). Mixed cultures (in Europe) are not an exclusively British phenomenon. Bjurström's description of Sweden is not convincing, especially as concerns Stockholms' suburban life, where we meet ethnically mixed youth groups every day. In summary: despite the complexities of reality and its contradictions and irrespective of declarations as to the need for a more dynamic view on modern culture, the construction of cultural separateness via simplified polarisations continues to be the dominant discourse in Sweden.

\section{Bricolage and new communities}

In connection with research on immigrant women I have previously discussed cultural identity work in terms of cultural bricolage ( $\mathrm{llund}, 1991$ ). That is, a transcending of cultural boundaries in time and space amalgamating a variety of experiences, life forms and idioms in ways which, perfectly well. 'equip their users to think their own world' (paraphrasing Hebdige, 1983: 103). These current forms of social communication through networking and bricolage draw attention to the past in the present ( $\AA$ lund, 1991). Continuously relating themselves to their own mothers', mythological or archetypal womens' pursuits Yugoslav immigrant women illustrate the importance of the ethnic memory for identity work. Rebellion and community of the past, the traditional female subculture in the Yugoslav village, lives on through the agency of new forms of resistance in immigrant communities. Intersecting time and space as a source of recognition, networking and consciousness concerned with both old and new antagonisms the past makes itself felt in the present. 
Alekdandra Alund

The continuous recognition of a common history is transferred from the mothers to the daughters. Among girls there is often a pronounced desire to re-discover their origins. For most Yugoslav immigrant youth this entails a journey back 'home'. One young girl, Lisa, travels to Yugoslavia to find 'the real' homeland. Yugoslavia, often referred to as 'the homeland', is perceived in terms of challenges linked to a search for belonging and identity, for one's own 'home'. The 'home' represents a multifaceted metaphor for immigrant youth. Lisa travels every year back home together with her parents. Daily (in Sweden), through collective memories, she revisits living relatives and the burial places of her dead grandmothers. The 'journey home', thus, takes place (geographically and symbolically) both in Yugoslavia and in Sweden.

One year Lisa travels alone on a prolonged journey to the homeland Yugoslavia, but merely to find that she is only partly at home. She identifies homelessness there with similar forms of homelessness in Sweden. Eventually she finds that her path is traversed by and resembles that of fellow travellers in her multicultural circle of friends in the Stockholm suburbs from where the trip home began. This circle of friends consists of an ethnically mixed group of girls and boys with shared ongoing journeys 'home'. Serbian Lisa has as her best friends a Turkish boy, an Italian-Swedish and a Swedish girl. The rest of her circle includes about a dozen youth, mostly boys from the Muslim Mediterranean area. Their identity work in the multi-ethnic suburban tenements demands that they actively create a cultural consciousness which is more comprehensive than that of their parents. This circle of friends, both boys and girls, via its ethric mix, not only includes most of what can be found in the local little world. It also constitutes a new form of community which calls into question and rework traditional complexes of values belonging to this world, together with established attitudes as regards masculinity/femininity, friendship/emnity, etc. The pathways of mythological ancestors and the experiences of living kinsmen remain, however, benchmarks informing Lisa's own life. The transgenerational female network which continue to constitute one of Lisa's important frames of reference tends to consciously orient itself outwards, which assist and historically anchors her own, more extensive, experience of transcultural community and networking. It is in this context that her mothers' identity work and social networks gain their special meaning. ' Struggling for belonging in a common, modern 'shared home' the presence of tradition, as historical experiences of community and resistance embedded and reworked in the context of local female networks, is essential in order for Lisa not to get lost on the trip (cf Ålund. 1991).

The 'communal home' is a timely metaphor which, linked with concepts such as 'diaspora' and 'syncretic culture' (Gilroy, 1987; Bjorklund, 1989), relates ethnicity to cultural bricolage, youth's identity work, and new social movements in the modern city. Through their position as youth, immigrants and 'Swedes', immigrant youth represent brokers in possession of information and experiences anchored in several social and cultural worlds. Via cultural bricolage, a flow of meanings and messages which circulate within and between different cultural groups, people transform themselves and their mutual relations; this is especially true in the socially and culturally open context of youth. In this sense, new cultural styles may express emerging transethnic interests and orientations. We can observe a new variety of expressive cultures, a differentiation of meaning and a ramification of the message structure. But it would be, in the above perspective. too shallow simply to conceive of the syncretic result of intercultural encounter in time 
and space as mixtures of style. The modern ethnic consciousness does not harvest its composite symbolic decor solely from the field of the modern cultural supermarket. New cultural forms express a creative and constructive connection with the past. They reflect struggles with the past's symbolic 'ghosts' and 'roots' which simultaneously may lead to both reconciliation and emancipation. These struggles may clear a path for new forms of community.

\section{Wrestling with ghosts}

In a previous work (Schierup and Ålund, 1987) we have discussed how active grounding in the local residential milieu creates possibilities for the development of new forms of cultural and social life among young Yugoslav immigrants in Scandinavia. But new forms of participation and organisation around communal interests also show themselves to be grounded in ethnic memory. Among the Wallachians of north-eastern Serbia, now living in Denmark and Sweden, symbols of a traditional order operate in new ways. 'Vampires', ghosts of deceased kinsmen, represent the authority of the elders and sanction intergenerational interdependency. In Scandinavia, the vampires become a symbolic guard against social fragmentation and new forms of blood-sucking: discrimination, marginalisation, social and work-related degradation.

'Vampires', most often, make their return in conjunction with intergenerational conflicts, when the order of the elder generation is threatened by both traditional forms of rebellion and new forms linked with cultural reorientation and economic independence of young people. The ghosts usually come at night, in fantasies and dreams. For example, a deceased mother would accuse her only son, Milorad, of having abandoned her, married against her will and by this discarded his responsibility for the household. Milorad does not believe in ghosts, but, nevertheless, the vampire believes in Milorad and mother continues to reappear. We can interpret these recurrent visits as an expression of Milorad's ambivalence towards the Scandinavian society that he attempted to make his own by casting off tradition. Finding himself isolated and stigmatised, however, Milorad, eventually (like Saladin in the Satanic Verses), realised a necessity of seeking his way back to his countrymen and, at least provisionally, to come to terms with tradition, kith and kin. While Milorad, following established custom, conducts a public memorial ceremony and begs his mother for forgiveness, he forces her to rest in peace. But he also strengthens his position and respect in the local immigrant community which he strives to transform. By reconciliating himself with tradition, thus coming back but at the same time looking forward, Milorad becomes accepted as an influential cultural middlemen. His original experience of traversing ethnic boundaries he now continued with a greater degree of security, this time not just as an isolated individual but as part of an outwardly-directed, organised collective. At the same time as he orients himself actively and politically toward other immigrant groups and toward Scandinavian society Milorad continues to cultivate (both for himself and as a leading figure in the immigrant association) a conscious rediscovering of his own tradition and his ethnic group's history. Milorad no longer whispers about his meeting with his mother's ghost.

The 'Vampire' reappears both as a sign of ongoing community conflicts and because of the need for reconciliation between the generations, but even signifying resistance in a communal experience of domination. In transformed gestalt, these old ghosts, the symbolic presence of tradition in the present, bear a new message. In the specific 
intersection between old and new antagonisms faced by immigrants, novel insights are released. These become transmuted or maybe rather amalgamated into new forms of social community, in which the symbols of kinship and village community attain their place next to that of modern solidarity. These new insights are maintained by subsequent generations of young Yugoslavs for whom the old 'Vampires' show themselves to represent symbolic blood-givers for the construction of new contexts of meaning and ways of life (ibid.).

The dynamics of the ethnic memory, the ability to connect the present with the past, and its antagonisms with those of the present, become actualised in the stormy existence of being an immigrant. The conflicts between discontinuance, marginalisation and fragmentation on the one hand and the hunger for warmth, community and human dignity on the other hand, spawn ways of life embraced by the diaspora of immigration (Gilroy, 1987; Røgild, 1989). The pulsating new life-styles inhabiting western Europe's cultural and social backyards are examples of this dynamic and creative power.

The past in the present: modern ethnic literature

Emerging forms of ethnic consciousness reveal a challenging potential which is central to a discourse on modernity (Berman, 1983; Edmundson, 1990). The modern ethnic literature is full of examples of a genuine vigour which signal the presence of the past in the present, a condition often depicted with aesthetic uniqueness and vibrant creativity. The narratives seem to be based on rebellion against both traditional and modern forms of violation. Here an often appearing self-inquiry which speaks through heavily loaded metaphors, both confirms and challenges the insecurity that is the hallmark of modernity.

An interesting example of the significance of ethnic memory for identity work comes from Zoe Wicomb (1987), a South African who lives in Glasgow. Her visit home to South Africa, in the guise of Frieda Shenton, represents a kind of self-scrutiny which results in Frieda achieving new insights in her state of being an outsider: That is concerning her own conditions of exile in Britain as well as an alienation in relation to new forms of rebellion belonging to the younger South African generation. Looking back, she realises that she 'got lost' in a racist society. The good education she received was not sufficient for her to scale the fence around the Whites'welfare. As black, she attains neither freedom nor security, neither in South Africa nor in Britain. The barrier seems, rather, to be transcended with the help of her own ethnic legacy which she had attempted to cast off. Returning to South Africa her identity work is aided by her mother's ghost. Frieda becomes involved in a conversation with her mother about how wild bushes defy the power of a fence, sprouting their stalks on the other side. Frieda realises that the bushes are part of the ethnic legacy she had cast off. The bush's longing for freedom does not disappear because of a fence. To find one's own place in the world and in history is connected to a revolt against the delusions of one's own adolescence as well as to spectres of the past who do not always speak the clear language of Frieda's mother.

This becomes obvious in the American Maxine Hong Kingston's Memories of Girlhood (1975). In her encounter with ethnic memories she calls herself a 'woman warrior among ghosts'. The point of departure is the experience of a rejected, dishonoured, 'nameless' paternal aunt. The aunt is sent from her in-laws' home back to her parents' because of infidelity and pregnancy with a man whose name she refuses to divulge. With her actions she threatens the traditional sexual and societal order: in her 
own kin group and in the village, which, in its fatalistic mode of looking at things, attributes to unforeseen results in the form of accident and death. The aunt drags shame upon her kin and is accused of having (socially) 'murdered' her own family. In way of defence, they label her a 'dead spirit' or ghost. She is driven to suicide and in mercy also takes her infant son with her, since he, too, is 'without family'. A son to a living ghost has himself no link to the family and can neither honour nor find the grave of a nameless and condemned mother. Fifty years after her suicide the aunt 'pursues' the author, who wants to know her real name: if she cannot see the aunt's life ramifying in her own, then she gets no help from the paternal legacy in her own present crises. Kingston allows her present ego, affect the past (cf. Berman, 1983). She confronts her own evaluations with those of her aunt's, her unease over that she herself, like once the aunt, can be driven away from home. She seeks her own 'name' while she tests her own limits. Does she herself have the right to her own private life, or will also she become nameless in the family's sitting room? The aunt broke with the tradition that women should hold onto the past against the tidal wave of change. In the midst of her era's tidal wave of changes, Kingston seeks her way home in a way which resembles that of Milorad. She comes to inherit a green address book containing names of family members in China to whom she, like the mother, will probably continue to send money. Contact with the old home is important for her anchoring in time and in essential communities. However, in her reconciliation with her background she herself attempts to 'name' or rather 'rename' the aunt, to retell the story, to find her own truths. She endeavours to choose her own heroines - be they gods or ghosts and bring them into daylight.

Instead of remaining silent about shame or living with lies, separate from other people as her parents, she lets a vicarious gestalt, a woman from the world of Chinese legends, represent an alternative ramification of her cultural patrimony. She relates the story of a woman who learns to cherish the other and, in spite of seemingly irreconcilable borderlines, makes the different a force for liaison and inventive change. This woman, the daughter of a learned and famous man, was kidnapped by a barbarian chieftain. She discovers a common language with the primitive barbarians and comes to appreciate their music. They come to understand the sorrow and anger in her songs. Her song blends with the music of their flutes. They learn to approach each other. When she is subsequently exchanged and comes back to her own people, she takes with her the new music, her song to the barbarians flutes. It comes to be sung by Chinese who accompany it with their own instruments. The song becomes a success also in translation, concludes Maxine Hong Kingston. It is here in the translation and merging of experiences that the ethnic literature has its power.

\section{Symbolic dramas of identity work}

The modern identity is difficult to grasp, compounded of many elements and changeable, full of inner tensions. At the same time as the modernisation process expands to encompass practically the entire world, while the emerging 'world culture of modernism achieves spectacular triumphs in art and thought', at pace with it, 'as the modern public expands, it shatters into a multitude of fragments, speaking incommensurable, private languages' (Bergman, 1983: 17). 'The idea of modernity, conceived in numerous fragmentary ways... loses its capacity to organise and give meaning to people's lives', as Berman (ibid.) expresses it. A result of this can be 'that we stand today in the midst of a 
modern age which has lost touch with the roots of its own modernity' (ibid.). In his essay on Goethe's Faust, about the breakthrough of modemism and the breaking up of the traditional 'Little World', Berman describes this world as a 'closed town' which because of its lack of will or incapacity to develop at pace with its own children becomes a 'town of ghosts', a world where 'its victims' ghosts will be left with the last laugh' (ibid: 59).

The 'ghosts' constitute a symbolic drama in the rootlessness of modernity; a contemporary metaphor which, in the midst of the whirl of emerging transnational communities and global cultural processes, exposes the problem of culturelessness, or rather a tendency of culture to free itself from its social context and from history. On the one hand there is an expansive globalisation of culture which outshines or tones down particular cultures and traditions. On the other hand there is a remaining dominance of cultural truths connected with a worship of the West and a belief in the superiority of its technological triumphs. Taken together, these contribute to the dissolution of the 'little world', raped by highways which penetrate their local neighbourhoods, fragmented into groups of insecure, introverted communities and families, detached and solitary, speaking mutually incompatible languages. Today's 'closed cities' occupied by modern forms of conservative or uniformly ethnocentric mythical creations may resemble the closure of traditional society and their crisis, the breakdown of the old world. Cracks in past times' traditional society evolved, according to Berman, primarily via contact with deviant patterns which came from the outside and due to the inner development which their own children were exposed to in their search for the freedom to think, love and expand. Also todays closed cities are marked by a multitude of escape attempts, journeys inwards as well as a restless roaming around the world. But at the same time the modern escape attempt seems to reflect a condition of homelessness and an urge to take one's own place in a local little world, exposed to a peripheral position in the larger world's monitoring, disciplining and segregating programming of life. Placed in segregated age-niches or excluded onto the streets, youth form new communities disturbing public order in the closed city.

They seek a place of their own, the unique and particular within the communal, the universal. The yearning to label their own culture and social life can take different forms: enclaves, introverted encapsulation and reactive, authoritarian forms of social and cultural assertion. The everpresent competition for social and cultural control of space frequently leads to a focus particularly on youth violence, ethnic conflicts and their connection with each other. But this longing can also be expressed in journeys across the boundaries of time, space and culture, in the seeking after new forms of grounded presence, personally as collectively. It is in these 'journeys' where the modern world also contains a potential for transcendence and renewal. This is especially true as concerns the young generations of immigrants with a modern ethnic consciousness as an increasingly more comprehensive form of modern existence. While modern society creates insecurity, the breakdown of close social ties and the dissolution of the fixed world, it also offers possibilities for the loosening and transcending of social and cultural borderlines. This potential is contained especially in the presence of ethnic variety in the modern global city. In a climate of cultural tumult and social fragmentation, the interaction between ethnicity and modernity offers new pathways towards this kind of transcend. ence.

In the current debate on Western civilisation ${ }^{2}$ emphasising the disintegration of public life, detraditionalisation and a general identity crises, we find a connection with a classical 
discussion (Durkheim, Weber, Tönnies) about disintegration of society and the need for new frames of reference. Cohen \& Taylor (1978; see also, Dahl, 1984), in a contribution to this debate, point to important changes in everyday existential conditions. People are becoming preoccupied with identity work so as to avoid being passively swallowed by an endless stream of pre-manufactured images, meaning and life-styles. The necessity for identity work is, so to say, a modern phenomenon.

We orient ourselves in everyday life by means of a variety of constructions of meaning and behaviour. These constructions form a sort of 'paramount reality', the totality of strategies, with which we are forced to live in order to manage the realities of everyday life. Cohen and Taylor call this 'reality work'. We live in what we conceive as several realities, or life-worlds. While these life-worlds and contexts are constantly shifting, there seems to be something which we always bear with us - our identity. However, this identity is not immediately given. There is a risk that we just float around in a growing variety of different life worlds; that we unconsciously adapt behaviour to the rules of the life-worlds within which we find ourself at the moment. Hence, there is a need not just for reality work but for identity work. In identity work we attempt to escape from paramount reality. Such attempts might take the form of extreme preoccupation with one's own body or health, or other escape valves like travelling, hobbies, gambling, risk-taking, overwork, drugs, sexual experiments, alternative life-styles, social movements etc. However, within Cohen and Taylor's framework, identity work remains no more than just attempts to escape. This is because identity work occurs in a historical situation marked by pervasive detraditionalisation and by the predominance of prepackaged styles which are bought and sold on the market place. For Cohen and Taylor the 'escape' becomes the expression of a particular dialectic between real needs and the culture industry's simultaneous articulation and distortion of these needs.

In contrast to Cohen and Taylor, Ziehe and Stubenreich (1983) argue that modern youth has a border transgressing potential, which emerges out of spiritual visits into historical, past cultures or contemporary, alternative cultures. This reservoir of alternative knowledge can be activated in new experimental ways, and it finds expression in several contemporary social movements. The identity work of immigrant youth reflects their access to alternative cultural frames of reference and social networks. In this sense, identity work among immigrant youth may constitute a long-term survival strategy rather than a fortuitous escape attempt (Schierup and Ålund, 1987). New inter-ethnic urban social movements can help integrate the individual's identity work with struggles for concrete material benefits, needs and political influence.

\section{Dialectics of the trip 'home'}

In his exposé discussing the emergence of syncretic cultural forms in British urban environments, Gilroy (1987) calls altention to the potential contained in the identity work of black and ethnic youth. An important example is the emergence of new composite languages (based for example on mixtures of cockney and creoles), which point to complex forms of transcultural communication. The identity-creating foundation embedded in the cultural variety of the local milieu, along with the shared language, signifies a struggle for control over one's own existence against authorities, dominant cultural norms, racism and discriminating control. Similar social and cultural experiences in local communities can unit Black and White youth, especially those from working class 


\section{Alekdandra Alund}

backgrounds. An amalgamation of cultural expressions such as thanguage, music and other forms of interaction, symbolises mutuality in a common struggle to reconstitute a 'collective historical presence' beyond the divisive, fragmented forms of existence; in the inner cities of Great Britain as more generally in the diaspora of migration (Gilroy, 1987: 236). From a historical perspective, it is a question of a long term ethno-cultural amalgamation processes which include a dynamic merging of the legacy from anti-colonial resistance with new forms of struggle rooted in modern urban contexts.

Modern multicultural societies generate new forms of social movements which, following Melluci (1980), can be described as movements oriented towards achieving a measure of autonomy vis à vis the system. Corporative structures in the formal political life and their forms of monitoring from above push groups of people on to the outside, segregate and threaten to paralyse the local community's own rhythms of life. It is in this perspective that we should understand Stuart Hall's description of the pulsating 'rhythms of life from below'. As 'rhythms of life' these new social movements represent 'symptoms of resistance to domination' rather than 'ready made agents for structural change' (Gilroy, 1987: 321). The new consciousness and the forms of community which they generate are related to major structural tensions in society, a common inequality and a shared outsider identity. A feeling of community and belonging in local contexts, constitute important preconditions for these groups of ethnic strangers to find their way to a common 'home' for white, 'ethnics' and black. In this sense informal forms of revolt, eg. alternative theatre performances (as, for example 'Under the Hawk's Wings' in Swedish Örebro), Rock Against Racism, music, and community, may represent more forceful strategies against racism than an often jeopardising moral appeal from above.

This type of emerging urban cultural amalgamation can be seen as embodying potentials of a generally significant 'modern ethnic consciousness' (cf. Bergman, 1982), probably most clearly articulated within the growing ethnic literature. One of the ethnic genre's prominent and challenging representatives is Salman Rushdie. whose Satanic Verses concerns the conditions for change and creativity in the global dialogue. The novel calls into question the absolute truths and proposes a way of possibly transcending them (Edmundson, 1990). Cultural amalgamation in the mulitude of symbolic messages can stimulate new forms of understanding, which extend the limits of the universally human. Homelessness is again a central metaphor with immigrants as the main actors. Beyond nostalgia homelessness allows for change and for the creation of a multicultural self. 'Rushdie's immigrants are pluralistic beings, and this pluralism seems to release unexpected sources of energy and wit among them' (ibid). In contrast to mainstream postmodern cultivation of deconstructive fragmentation, an emancipatory constructive amalgamation stands here out as a possible, positive altemative to the crisis of modem consciousness.

As we have discussed, 'the way home' can be found after a dialogue and an exchange over time and space, culture and identity. The discourse of modernism. which for Berman leads deeper into modernism, enriches us with its recurring confrontation. Yet it also carries with it a uni-dimensional focus on change as dissolution which risks leading us astray. The dialectic of coming back and reforming (as in the experience of, for example, Milorad) expresses a constructive outcome of young immigrants identity work. Experiments and journeys across the border are only likely to be successful, if one has something fairly stable to return to (Dahl, 1984). New social movements need local ties and 
obligations which, while they may constrain the development of a cosmopolitan world consciousness, enable people to think about the future in constructive ways instead of giving themselves over to narcissistic despair or cosmic panic (paraphrasing Lasch, 1984: 14ff). Autonomous local organisation and attachment to a face-to-face community are preconditions for constructing a public personality and a meaningful political organisation. Local attachment and personal links must exist in order to be transcended. Ghosts have to be named in order to be renamed.

\section{Notes}

1. In the book Lilla Juga ('Little Yugoslavia') this is illustrated with a series of concrete examples; see Ålund (1991).

2. For examples, Riesman, Fromm, Coser, Marcuse, Sennett, Lasch.

\section{References}

Arnstberg, Karl-Olov (1989). Svenskhet, Den kulturförnekande kulturen. [Swedishmess: The Culture-Denying Culture]. Carlssons, Malmo.

Berman, Marshall (1983). All that is solid melts into air. The experience of modernity, London: Verso.

Bjurström, Erling (1985). 'Kan invandrarungdiomar välja kultur? En kunskapsöversikt.' [Can immigrant youth choose culture? A survey of the literature] In: Uppväxt villkor $\mathrm{Nr} 2 / 85$. Statens Ungdomsrdd, Stockholm (pp. 7-45).

Bäck, Henry (1989). Jugoslaviska invandrarföreningar i Sverige. [Yugoslav Immigrant Associations in Sweden], Centrum för invandringsforskning, Stockholm.

Cohen, S and Taylor, L. (1978). Escape Attempts. Penguin, Hammondsworth.

Dahl, Göran (1984). 'Gränser och ny kultur' (Boundaries and new culture), Bokbox (81: 36-46).

Daun, Åke och Ehn, Billy (ed.), (1988). Bland-Sverige, Kulturskilhader och kulturmöten. [Mixed Sweden: Cultural Differences and Cultural Encounters] Carlssons, Stockholm.

Edmundon, Mark (1990). 'En profet för kulturernas sammansmältning'. (A Prophet of the Amalgamation of Cultures] Dagens Nyheter, 3 april 1990: B3, Stockholm.

Ehn, Billy (1985). 'Svensk daghemskultur, strategi mot skillnader.' [Swedish Day Care Centre Culture: Strategy Against Cleavages] In: Uppväxt villkor Nr 2/85, Statens Ungdomsråd, Stockholm (pp. 55-65).

Gilroy, Paul (1987). There Ain't No Black in The Union Jack, Hutchinson, London.

Hannerz, Ulf (1983). Över gränser. [Crossing Boundaries/ Liber, Lund.

Hannerz, Ulf (1990) 'Stockholm: Double Creolising', paper for the International Conference on the Organisation of Diversity: Botkyrka, Sweden, as a Multicultural Setting.

Hebdige, Dick (1983) The meaning of style, London: Methuen (first published 1979).

Hermansson, Hans-Erik (1988). Fristadens barn, Om ungdomars livsstilar, kulturer ach framtidsperspektiv. /Child of the Free City: On Youth, Life Siyles, Cultures and Future Perspectives]. Daidalos, Göteborg.

Jones. Simon (1988), Black Culture White Youth, MacMillan Education, London.

Kingston, Hong, Maxine (1976). The Warrior: Memory of a Girlhood among Ghosts. New York: Knopf. (Swedish translation: Norstedıs \& Söners Förlag. Stockholm, 1978).

Kotsinas, Ulla-Brilt (1985). 'Invandrarsvenska och språkförendringar' [Immigrant Swedish and Language Changes] In: Svenskans beskrivning, Bil.14. Güteborg.

Lange, Anders (1987). Identifications, Perceived Cultural Distance and Stereotypes in Second Generation Yugoslav and Turkish Youth in Srockholm. Report No.14. Centrum för Invandringsforskning, Stockholms Universitet. 


\section{Alekdandra Ålund}

Lasch, C. (1984). The Minimal Self. Psychic Survival in Troubled Times. W.W. Norton, New York. Lithman, Yngve, (1982) On Culture and Identity. EIFO, Pil-rapport Nr 7.

Lithman, Yngve (1987) (ed.) Nybyggerna i Sverige. Invandring och andra generation. [Pioneers in Sweden: Immigration and the Second Generation]. Carlssons.

Löfgren, Horst (1984). Invandrarungdomar i skolan och pd arbetsmarknaden. [Immigrant Youth in School and on the Labour MarketJ. Report 32 and 38, Pedagogisk inst. Lunds Universitet.

Marin de Vidal, Mary (1989). 'Alt bo i Sverige'. I: I Hjärtat av Tensta, Dikter, Berättelse och bilder fran Tensta gymnasium. [To Live in Sweden. In the Heart of Tensta - Poems, Stories and Pictures from Tensta High School]. Tensta Gymnasium, Stockholm.

Melluci, A. (1980). 'The New Social Movements: A Theoretical Approach', In: Social Science Information, 19 (2).

Ouvinen-Birgerstam, Pirjo (1984). Identitetsurveckling hos barn, En jämförelse mellan finska, jugoslaviska och svenska barn. [Identity Development in Children: A Comparison of Finnish, Yugoslav and Swedish Children]. Studentlitteratur, Lund.

Rasmusson, Ludvig (1990). 'Från Sankt Göran och draken till Titiyo' [From St. George to Titiyo], Ny i Sverige (5): 2-7.

Rögild, Flemming (1988). Rytme, racisme \& nye rödder. [Rythym, Racism and New Roots]. Politisk Revy. Copenhagen.

Schierup, Carl-Ulrik and Ålund, Aleksandra (1987). Will They Still Be Dancing? Integration and Ethnic Transformation among Yugoslav Immigrants in Scandinavia, Almqvist \& Wiksell International, Stockholm.

Sennett, Richard (1977). The Fall of Public Man. Cambridge University Press, Cambridge.

Similä, Matti (1987). Kulturell identitet hos unga invandrare. (Cultural ldentity among Young Immigrants]. Centrum för invandringsforskning, Rapport 7/87, Stockholms Universitet.

Stroud, Christopher och Wingstedt, Maria (1989). 'Språklig chauvinism?'. [Linguage Chauvinism], In: Invandrare \& Minoriteter, $\mathrm{Nr} 4-5 / 89$, Stockhom (pp.5-9).

Tengvall;, Gunilla (1986). 'Ett nytt Sverige växer upp i Rinkeby'. [A New Sweden Grows up in Rinkeby] Dagens Nyheter, 25 maj 1986: 33-34, Stockholm.

van Niekerk, Mies (1987). 'Immigrant girls: Ethnicity and Gender' In: Migracijske teme, No 3/87, Zagreb (pp.65-73).

Westerberg, Boel (1987). Det är ju vi som är negern. Om kultirmöten i skolan [It is we who are the negroes: on cultural encounters in school], Dialogos. Lind.

Westin, Charles (1987). Den toleranta opinionen, Inställning till invandrare 1987. [The Tolerant Opinion: Attitudes toward Immigrants]. Rapport $\mathrm{Nr}$ 8. Delegationen för invandrarforskning, Stockholm.

Wicomb, Zoé (1987). You Can't Get Lost in Cape Town. Virago Press.

Willis, Paul. (1977). Learning to Labour. Gower, Hampshire.

Ziehe, T. \& Stubenrauch, H. (1983). Plädoyer für Ungewöhnliches Lernen, Ideen zur Jugendsituation (A plea for unusual learning. Ideas to the situation of youth). Rohwohlt, Hamburg.

Ålund, Aleksandra (1985). Skyddsmurar, Etnicitet och klass i invanddrarsammanhang. [Protective Walls: Ethnicity and Class in the Immigrant Context] Liber, Stockholm.

Ålund, Aleksandra, (1988). 'The Power of Delinitions: lmmigrant Women and Problem-Centred. Ideologies'. In: Migration No.4: (37-55).

Ålund, Aleksandra (1991). Lilla Juga, Etnicitet, familj och kvinnliga nätverk $i$ kulturbrytningars iid, [Little Yugoslavia: Ethnicity, Family and Female Networks in an Age of Cultural Rupture] Carlsson Förlag, Stockholm(1991). 